\title{
Preparation and Hydration Mechanism of Mine Cemented Paste Backfill Material for Secondary Smelting Water-granulated Nickel Slag
}

\author{
Feng Wang ${ }^{1}$, Qiangqiang Zheng ${ }^{1}$, Guangquan Zhang ${ }^{2 *}$, Changlong Wang ${ }^{3,4,5^{*}}$, Fang Cheng ${ }^{6}$ and Geng Lin ${ }^{7}$ \\ ${ }^{1}$ School of Civil Engineering and Architecture, Anhui University of Science and Technology, Huainan 232001, China; \\ ${ }^{2}$ School of resources and environmental engineering, Wuhan University of Science and Technology, Wuhan 430081, China; \\ ${ }^{3}$ School of Civil Engineering, Hebei University of Engineering, Handan 056038, China; \\ ${ }^{4}$ Jiangxi Key Laboratory of Mining Engineering, Jiangxi University of Science and Technology, Ganzhou 341000, China; \\ 5 Tianjin Sunenergy Sega Environmental Science \& Technology Co. Ltd, Tianjin 300380, China; \\ ${ }^{6}$ School of Water Conservancy and Hydroelectric Power, Hebei University of Engineering, Handan 056038, China; \\ ${ }^{7}$ School of Chemistry and Chemical Engineering, Xi'an University of Science and Technology, Xi'an 710054, China.
}

Corresponding Author Email: zhanggq@wust.edu.cn; baistuwong@139.com

\begin{abstract}
Using secondary smelting water-granulated nickel slag (SWNS) after iron extraction as the main raw material, made composite activator (flue gas desulphurization gypsum (FGDG) and carbide slag (CS) are the main activators, $\mathrm{Na}_{2} \mathrm{SO}_{4}$ and cement clinker (CC) are the auxiliary activators) with cementing agents (CA), and then made into mine cemented paste backfill (CPB) material with iron ore tailings (IOT). The factors affecting the mechanical properties such as the composition of raw materials and the amount of activator were studied by means of mechanical property test, X-ray diffraction (XRD) and scanning electron microscope (SEM), the ratio of CPB material was optimized, and the hydration mechanism of CPB material was analyzed. The results show that when the mass fraction of SWNS, FGDG, CS, Na2 $\mathrm{SO}_{4}$ and CC in $\mathrm{CA}$ is $85 \%, 5 \%, 5 \%, 3 \%$ and $2 \%$. The $28 \mathrm{~d}$ flexural strength and compressive strength of CPB material of SWNS reach $1.99 \mathrm{MPa}$ and 3.38 $\mathrm{MPa}$, which meet the strength requirements of mine CPB material. The results of X-ray diffraction (XRD), scanning electron microscope (SEM) and hydration mechanism analysis showed that both vitreous and crystalline substances in, CA of SWNS could be hydrated, and the main hydration products were ettringite $(\mathrm{AFt})$ and $\mathrm{Ca}^{2+}, \mathrm{Mg}^{2+}$ containing hydrated aluminosilicate (C-M-S-H) gel.
\end{abstract}

Keywords: Secondary Smelting Water-Granulated Nickel Slag, Cemented Paste Backfill Material, Cementing Agents, Composite Activator, Ettringite

Received: December-06-2019, Accepted: January-06-2020, https://doi.org/10.14447/jnmes.v23i1.a10

\section{INTRODUCTION}

Cemented paste backfill (CPB) method refers to the backfilling mining method in which cementing agents (CA), aggregate and water are mixed in a certain proportion and stirred evenly, and then the filling slurry or paste is transported to the mined out area by gravity self-flow or pumping through the conveying pipeline [1]. The main function of CPB body is to meet the operational requirements of mining equipment and to provide artificial bottom pillars or false roofs, so the strength requirements vary according to the backfilling technology and the function of the backfilling body, which is generally 1 5 $\mathrm{MPa}$ [2]. High quality $\mathrm{CPB}$ mining can increase resource recovery rate by more than $30 \%$ compared with nonCPB mining. CPB is increasingly widely used as an effective mining technology for deep well, complex and special conditions ore deposits $[3,4]$. CPB is a new backfilling technique for mines, which allows the tailings harmful to the environment to return to the underground roadway or stope, so as to maximize the safety, efficiency and productivity of the process/operation, it is of great significance to solve the safety hazards and environmental problems caused by a large number of tailings stockpiling [5-8].

CPB costs generally account for $25 \% \sim 40 \%$ of the total mining costs, and $\mathrm{CA}$ costs account for $70 \% \sim 80 \%$ of the backfilling costs $[9,10]$. CPB materials are mainly composed of aggregate and CA, ordinary Portland cement (OPC) is used as cementing agent in most mines [11-14]. Cement, as the CA that has been used for the longest time and has been widely used in cementing backfilling, has the characteristics of stable strength development and reliable property, and has been widely used in mine filling. The most commonly used type of cement is OPC, but cement as a backfilling CA also has the following problems: (1) In the process of $\mathrm{CC}$ production, a large amount of coal, electricity, limestone, clay and other resources are consumed, and $0.95 \mathrm{t} \mathrm{CO}_{2}$ will be emitted for $1 \mathrm{t}$ of $\mathrm{CC}$ production, resulting in resource waste and environmental pollution. (2) When sulfide is present in tailings, the oxidized acid and sulfate of the sulfide will reduce the stability of the cement CPB material [15]. (3) The cost of cement CA accounts for $60 \% \sim 80 \%$ of the backfilling cost. Therefore, many mining enterprises and researchers began to look for industrial byproducts with low cost, excellent performance, environmental protection and cementitious properties, such as fly ash [16-19], nonferrous metallurgical slag [20], steel slag [21], GBFS [22-26] and other additives [27-29], the solid wastes with potential cementitious activity are partly or completely substituted for cement to prepare CA, it can not only improve the comprehensive utilization rate of industrial solid waste, but also protect the environment and reduce the cost of $\mathrm{CA}$, which has broad development prospect.

Non-ferrous metallurgical slag is the solid waste after the smelting of non-ferrous metals, mainly including the slag formed in the process of fire smelting and the residue 
discharged in the process of wet smelting. After mechanical grinding and chemical excitation, it has a good potential activity, and can be used to prepare CA for CPB material, and improve the utilization rate [20,30]. Nickel slag contains $30 \% \sim 40 \%$ of iron in the form of silicates, and further reduction smelting of this nickel slag can extract most of the valuable metal at one time. However, a large amount of SWNS is produced in the process of iron extraction by secondary smelting, after water-granulated, its appearance is close to that GBFS, but its chemical composition and material structure are quite different from GBFS, and SWNS has certain potential hydraulic properties [31-34]. If enough strength can be generated by the activator, it can be used in backfilling. In this study, FGDG, $\mathrm{CS}, \mathrm{Na}_{2} \mathrm{SO}_{4}$ and $\mathrm{CC}$ were used as activators. Through the factors affecting the mechanical properties, such as the composition of raw materials and the amount of activator, optimized the ratio of CPB material, and on this basis, the hydration process and mechanism of CPB material were analyzed by means of XRD, SEM and other testing methods. It provides a basis for the application of SWNS in mine CPB material.

\section{MATERIALS AND METHODS}

\subsection{Experimental materials}

The main materials used in the test are SWNS, CC, CS, FGDG, $\mathrm{Na}_{2} \mathrm{SO}_{4}$, IOT, its chemical composition is shown in Table 1, and the mineral composition of raw materials is shown in Figure 1.

Table 1. Chemical composition of raw materials (wt. \%)

\begin{tabular}{ccccccccccc}
\hline Materials & $\mathrm{SiO}_{2}$ & $\mathrm{Al}_{2} \mathrm{O}_{3}$ & $\mathrm{Fe}_{2} \mathrm{O}_{3}$ & $\mathrm{FeO}$ & $\mathrm{MgO}$ & $\mathrm{CaO}$ & $\mathrm{Na}_{2} \mathrm{O}$ & $\mathrm{K}_{2} \mathrm{O}$ & $\mathrm{SO}_{2}$ & $\mathrm{LOI}$ \\
\hline $\mathrm{SWNS}$ & 36.72 & 6.97 & 0.27 & 3.01 & 28.78 & 22.69 & 0.16 & 0.08 & 0.87 & 0.13 \\
$\mathrm{CC}$ & 22.50 & 4.86 & 3.43 & - & 0.83 & 66.30 & - & 0.08 & 0.24 & 0.96 \\
$\mathrm{CS}$ & 3.45 & 1.94 & 0.078 & 0.29 & - & 59.54 & 0.28 & 0.001 & 3.55 & 30.11 \\
$\mathrm{FGDG}$ & 3.16 & 1.35 & 0.47 & 0.09 & 7.49 & 33.38 & 0.13 & 0.18 & 36.56 & 8.28 \\
$\mathrm{Na}_{2} \mathrm{SO}_{4}$ & - & - & - & - & - & - & 43.23 & 0.008 & 44.62 & 0.002 \\
$\mathrm{IOT}$ & 68.96 & 7.68 & 2.32 & 4.47 & 3.64 & 4.35 & 1.41 & 1.85 & 0.024 & 2.49 \\
\hline
\end{tabular}

Table 2. Particle size distribution of IOT

\begin{tabular}{ccccccc}
\hline Sieve Size/ mm & +1.25 & $\begin{array}{c}-1.25 \\
+0.63\end{array}$ & $\begin{array}{c}-0.63 \\
+0.32\end{array}$ & $\begin{array}{c}-0.32 \\
+0.16\end{array}$ & $\begin{array}{c}-0.16 \\
+0.08\end{array}$ & -0.08 \\
\hline Meter sieve/\% & 1.5 & 5.8 & 6.9 & 36.8 & 41.2 & 7.8 \\
Cumulative sieve $/ \%$ & 1.5 & 7.3 & 14.2 & 51.0 & 92.2 & 100 \\
\hline
\end{tabular}
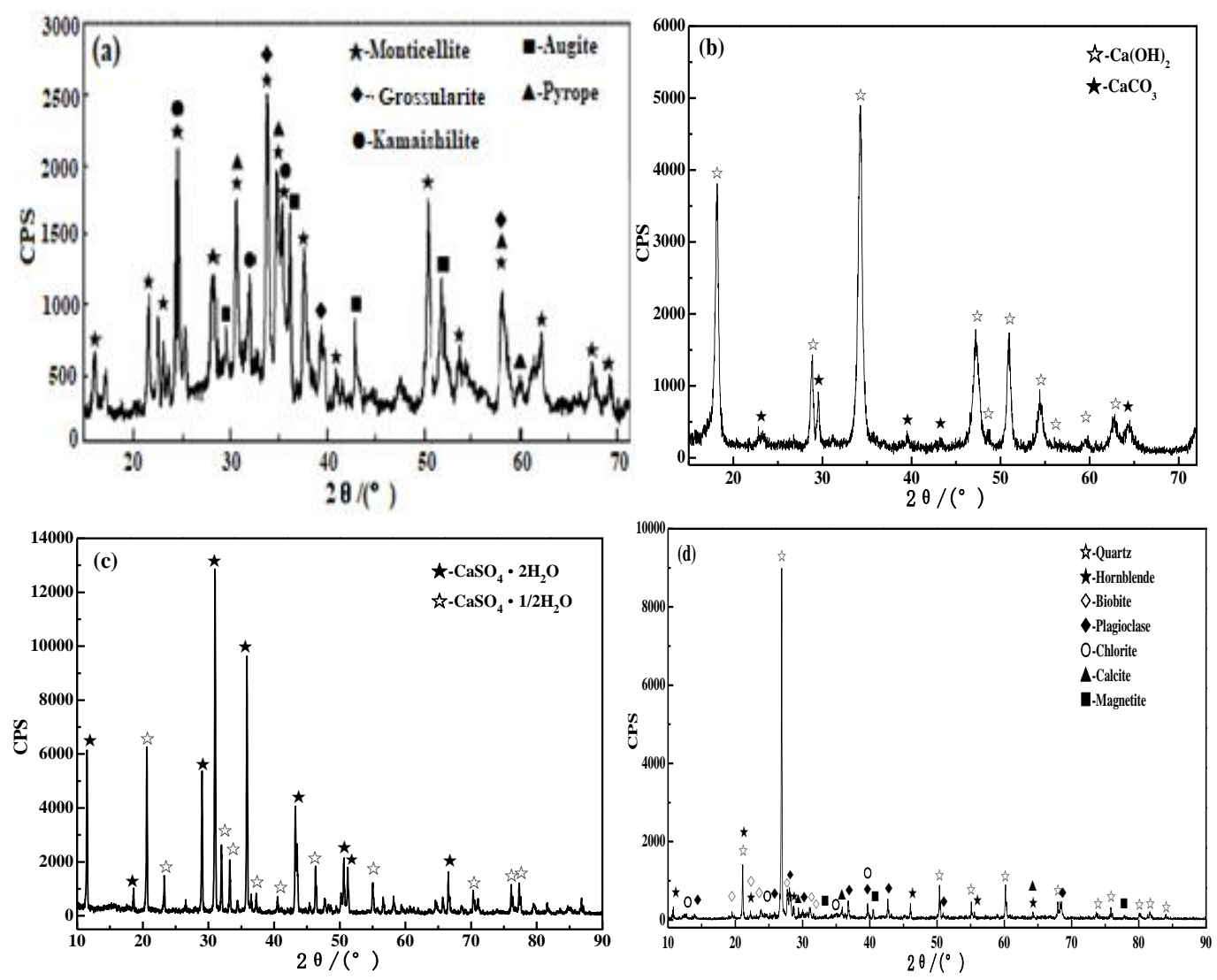

Figure 1. XRD spectrum of raw materials (a)-SWNS, (b)-CS, (c)-FGDG, (d)-IOT 
SWNS. The SWNS produced by molten reduction of iron extraction from nickel smelting slag was selected. The chemical composition is shown in Table 1, and the XRD analysis results are shown in Figure 1(a). It can be seen from Figure 1(a) that there are more crystals in SWNS, including monticellite, kamaishilite, grossularite, augite and so on. Fig. 2 shows the SEM microstructure of SWNS corroded, cleaned, dried and sprayed with $1 \%$ HF solution. As the hydrofluoric acid solution corrodes the glass phase on the surface, a large amount of crystalline materials is exposed on the glass phase. SWNS contains a large number of crystalline materials. EDS semi-quantitative analysis of crystalline materials and XRD analysis show that the crystalline materials of SWNS were monticellite, kamaishilite, grossularite and augite (Fig. 2(a)). In Figure 2(b), the labeled region A is a large amount of glassy materials, and the labeled region $\mathrm{A}$ is monticellite. This is because the generation of SWNS after the extraction of iron from nickel slag is similar to the generation of GBFS. By water-granulated and rapid cooling of molten nickel slag, glassy substances and crystalline substances with low hydration potential are generated, which have certain potential hydraulic activity. Due to the different content and composition of glassy materials, the strength of SWNS as a cementitious material is very different. Similar to GBFS, SWNS is also composed of $\mathrm{Al}_{2} \mathrm{O}_{3}$ and $\mathrm{SiO}_{2}$ to form a threedimensional network space, and alkali metals and alkali earth metals are embedded in the gaps of the grid. Under the action of the activator, the network structure of $\left[\mathrm{AlO}_{4}\right]^{5-}$ tetrahedron and $[\mathrm{SiO} 4]^{4-}$ tetrahedron was destroyed. $\mathrm{Mg}^{2+}, \mathrm{Ca}^{2+}, 6-$ coordination $\mathrm{Al}^{3+}$ and alkali metals were involved in the reaction of SWNS, forming hydrates and showing gelation [31-34]. However, there are great differences between SWNS and GBFS in this study, as shown in the following aspects: the chemical components of SWNS and GBFS differ greatly, and the formation of the final phase will follow the phase law of certain components, SWNS have more crystals. The formation of the hydration products of SWNS CA not only needs to stimulate the hydration reactivity of the glass phase, but also needs to stimulate the hydration reactivity of the crystalline phase to a certain extent.

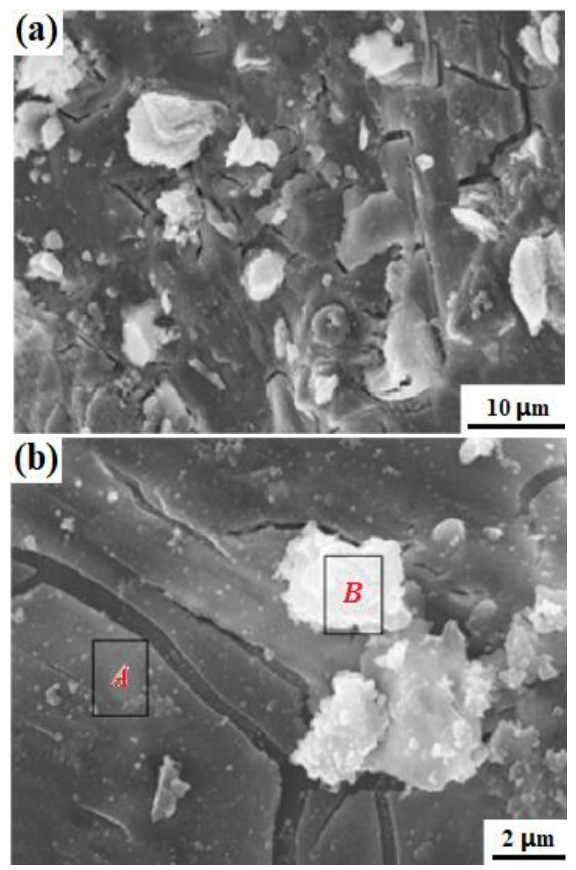

Figure 2. SEM images of SWNS after treated by $1 \% \mathrm{HF}$
(2) CC. CC is the OPC clinker produced by cement plant. The chemical composition is shown in Table 1, the main mineral components are $\mathrm{C}_{2} \mathrm{~S}(24.6 \%), \mathrm{C}_{3} \mathrm{~S}(55.7 \%), \mathrm{C}_{3} \mathrm{~A}$ $(8.8 \%)$ and $\mathrm{C}_{4} \mathrm{AF}(10.9 \%)$

(3) CS. Its chemical constituents are listed in Table 1. The $\mathrm{CaO}$ content of $\mathrm{CS}$ is $60.16 \%$, and its mineral composition is mainly $\mathrm{Ca}(\mathrm{OH})_{2}$ and $\mathrm{CaCO}_{3}$ (see Figure $1(\mathrm{~b})$ ), $\mathrm{CS}$, and the residue of $0.08 \mathrm{~mm}$ square-hole sieve is $12.8 \%$.

(4) FGDG. FGDG is the wet FGDG from the thermal power plant, and its main component is $\mathrm{CaSO}_{4} \cdot 2 \mathrm{H}_{2} \mathrm{O}$, Fig. 1(c). According to Table 1, the burning loss of FGDG was $8.28 \%$, the contents of $\mathrm{CaO}$ and $\mathrm{SO}_{3}$ in FGDG were $33.38 \%$ and $45.70 \%$, respectively. According to the calculation that all $\mathrm{SO}_{3}$ came from $\mathrm{CaSO}_{4}$, the mass fraction of $\mathrm{CaSO}_{4}$ in $\mathrm{FGDG}$ was $78.26 \%$, and the SSA was $210 \mathrm{~m}^{2} \cdot \mathrm{kg}^{-1}$.

(5) IOT. Its chemical constituents are listed in Table 1 . The particle size of tailings with a mass fraction of about $78 \%$ is between $0.08 \mathrm{~mm}$ and $0.32 \mathrm{~mm}$; those with a particle size greater than $0.32 \mathrm{~mm}$ account for $14.2 \%$; and those with a particle size of about $7.8 \%$ are less than $0.08 \mathrm{~mm}$ (see Table 2 ). The content of $\mathrm{SiO}_{2}$ in the tailings reaches $68.96 \%$ (mass fraction, the same below), which belongs to high-silicon type IOT. The major minerals of IOT included: quartz, hornblende, biotite, plagioclase and a few amount of chlorite, calcite and magnetite (see Figure 1(d)).

\subsection{Methods}

The experimental process of SWNS preparing CPB material is shown in Figure 3. Firstly, SWNS, CS and FGDG were dried in oven at $105{ }^{\circ} \mathrm{C}$ for $24 \mathrm{~h}$ to make moisture content less than $1 \%$, respectively. Then, crushed them using SM $\varphi 500$ $\mathrm{mm} \times 500 \mathrm{~mm}$ laboratory ball mill at the speed of $48 \mathrm{r} \cdot \mathrm{min}^{-1}$ to yield SSA of $550 \mathrm{~m}^{2} \cdot \mathrm{kg}^{-1}, 300 \mathrm{~m}^{2} \cdot \mathrm{kg}^{-1}$ and $330 \mathrm{~m}^{2} \cdot \mathrm{kg}^{-1}$. The grinding media consists of several steel balls and a steel forging. The loading mass of the grinding media should be 100 $\mathrm{kg}$. The steel balls add up to $40 \mathrm{~kg}$, in which the $\Phi 70 \mathrm{~mm}$ ball takes up $19.7 \%$, the $\Phi 60 \mathrm{~mm}$ ball takes up $33.1 \%$, the $\Phi 50$ mm ball takes up $29.6 \%$, and $\Phi 40 \mathrm{~mm}$ ball takes up $17.6 \%$; the $\Phi 25 \mathrm{~mm} \times 30 \mathrm{~mm}$ steel forging weighs $40 \mathrm{~kg}$. CC was first crushed to 1 3 mm with a jaw crusher, and then the ballmilling to SSA $400 \mathrm{~m}^{2} \cdot \mathrm{kg}^{-1}$. The prepared raw materials are mixed evenly in proportion to form $\mathrm{CA}$, then, in accordance with binder sand ratio (CA/IOT) of 1:4, IOT was added as aggregate and mixed evenly with water in the binder sand mixer to make slurry concentration of $80 \%$ mortar. After that, $4 \mathrm{~cm} \times 4 \mathrm{~cm} \times 16 \mathrm{~cm}$ cement binder sand triple test model was injected, after $24 \mathrm{~h}$ of shaking molding on the cement and sand vibrating table, the mold was taken off for curing, and the mold was put into a standard curing box with a temperature of $(20 \pm$ 1) ${ }^{\circ} \mathrm{C}$ and a humidity of more than $90 \%$ for curing, because the early strength is not high, after $7 \mathrm{~d}$, the mold is damaged and then put into the curing box for curing. Finally, the mechanical properties of the test block at different ages are determined. An optimized ratio was obtained by measuring the compressive strength of the samples, and the optimized ratio of CA was analyzed by XRD and SEM.

The SSA is measured using dynamic specific surface area analyzer (SSA-3200). The compressive strength test of samples was based on the Chinese National Standard GB/T 17671-1999 Method of testing Cements-Determination of strength. The hydraulic pressure testing machine (YES-300) with a maximum load of $300 \mathrm{KN}$ and a loading rate of $2.0 \pm$ $0.5 \mathrm{kN} / \mathrm{s}$ was used to measure compressive strength. The $\mathrm{X}$ - 
ray diffraction (XRD) spectrum of the samples were performed using a D/Max-RC diffractometer (Japan) with $\mathrm{Cu}$ $\mathrm{K} \alpha$ radiation, voltage of $40 \mathrm{kV}$, current of $150 \mathrm{~mA}$ and $2 \theta$ scanning ranging between $5^{\circ}$ and $90^{\circ}$. FE-SEM observation was performed to analyse the hydration products of the CA using a Zeiss SUPRA ${ }^{\mathrm{TM}} 55$ scanning electron microscope coupled with a Be4-U92 energy spectrum.

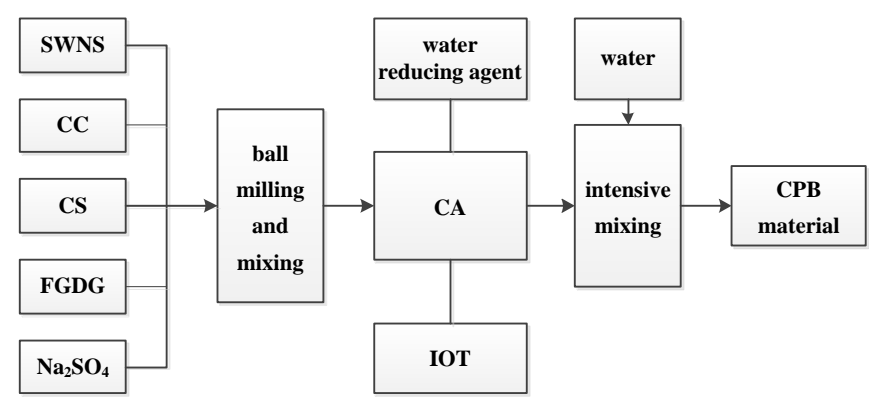

Figure 3. Process flow of CPB material prepared by SWNS

\section{RESULTS AND DISCUSSION}

\subsection{Properties of CPB material}

3.1.1 Effect of the amount of FGDG and CS on strength of CPB material

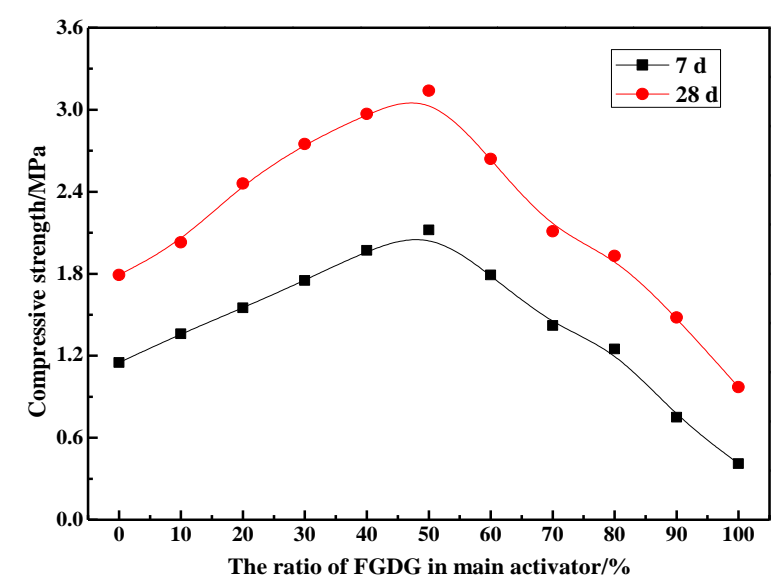

Figure 4. Effect of FGDG content on compressive strength of CPB material

Similar to GBFS, SWNS itself cannot generate strength by their own hydration, but can be generated strength by activator excitation. In this study, two kinds of industrial solid waste FGDG and CS were selected as main activators, $\mathrm{Na}_{2} \mathrm{SO}_{4}$ and $\mathrm{CC}$ as auxiliary activators, and the appropriate content of these activators was determined through experiments. FGDG belongs to sulfate activator and CS belongs to alkali activator. Only when the two activators reach a reasonable ratio can SWNS produce the best excitation effect. First fixed SWNS content in CA, the main activator and the auxiliary activator quality percentage were $85 \%, 10 \%$ and $5 \%$, and fixed in the auxiliary activator, the mass ratio of $\mathrm{Na}_{2} \mathrm{SO}_{4}$ to $\mathrm{CC}$ is $3: 2$ and FGDG accounted for the proportion of the main activator can be divided into $0,10 \%, 20 \%, 30 \%, 40 \%, 50 \%, 60 \%, 70 \%, 80 \%$, $90 \%, 100 \%$, and then according to the test method specified in section 2.2, determine the proportion of FGDG in activator. Figure 4 shows the effect of FGDG content on the compressive strength of CPB material of SWNS. It can be seen from Figure 4 that when the mass ratio of FGDG and CS is 5:5 (namely 1:1) and the sum of them accounts for $10 \%$ of CA, the compressive strength of the CPB material is the highest. The compressive strength of CPB material samples of SWNS on $7 \mathrm{~d}$ and $28 \mathrm{~d}$ is 2.12 $\mathrm{MPa}$ and $3.14 \mathrm{MPa}$, respectively, meeting the strength requirements of mine $\mathrm{CPB}$ material.

3.1.2 Effect of the amount of $\mathrm{Na}_{2} \mathrm{SO}_{4}$ and $\mathrm{CC}$ on strength of CPB material

Fixed SWNS content in CA, the main activator and the auxiliary activator quality percentage were $85 \%, 10 \%$ and $5 \%$, and fixed the main activator of FGDG and CS quality ratio is $1: 1$, change the auxiliary activator $\mathrm{Na}_{2} \mathrm{SO}_{4}$ quality percentage is $0,10 \%, 20 \%, 30 \%, 40 \%, 50 \%, 60 \%, 70 \%, 80 \%, 90 \%, 100 \%$, the change of the auxiliary activator content on CPB material samples of SWNS compressive strength and flexural strength, the test results are shown in Figure 5 and Figure 6.

As can be seen from Figure 5 and Figure 6, when $\mathrm{Na}_{2} \mathrm{SO}_{4}$ accounted for $60 \%$ of the auxiliary activator content $\left(\mathrm{Na}_{2} \mathrm{SO}_{4}\right.$ : $\mathrm{CC}=3: 2$ ), CPB material samples of SWNS showed the highest flexural strength and compressive strength on $7 \mathrm{~d}$ and $28 \mathrm{~d}$. Therefore, the mass ratio of $\mathrm{Na}_{2} \mathrm{SO}_{4}$ to $\mathrm{CC}$ is set as $3: 2$, that is, the mass fractions of SWNS, FGDG, CS, $\mathrm{Na}_{2} \mathrm{SO}_{4}$ and $\mathrm{CC}$ in CA should be $85 \%, 5 \%, 5 \%, 3 \%$ and $2 \%$, at this point, the compressive strength and bending strength of CPB material samples of SWNS on $28 \mathrm{~d}$ are $3.38 \mathrm{MPa}$ and $1.99 \mathrm{MPa}$, meet the requirements of CPB material for $28 \mathrm{~d}$ compressive strength $\geq 3.1 \mathrm{MPa}$ and $28 \mathrm{~d}$ flexural strength $\geq 1.9 \mathrm{MPa}$.

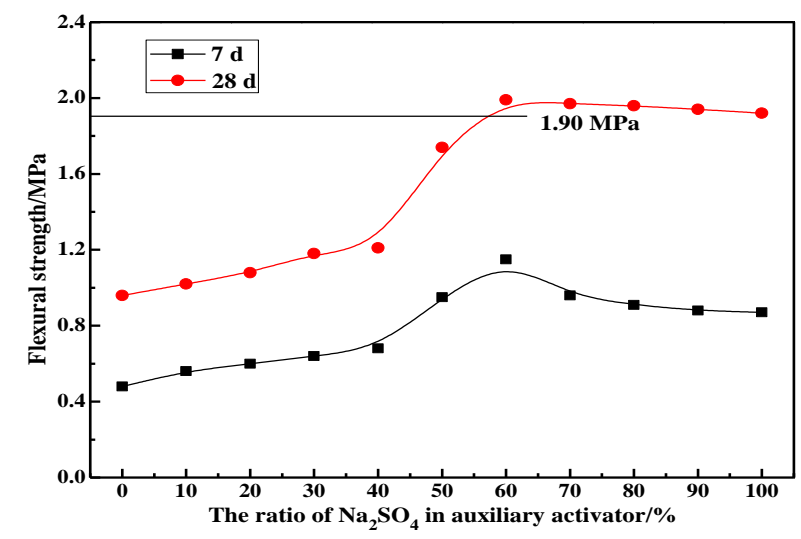

Figure 5. Effect of $\mathrm{Na}_{2} \mathrm{SO}_{4}$ content on flexural strength of $\mathrm{CPB}$ material

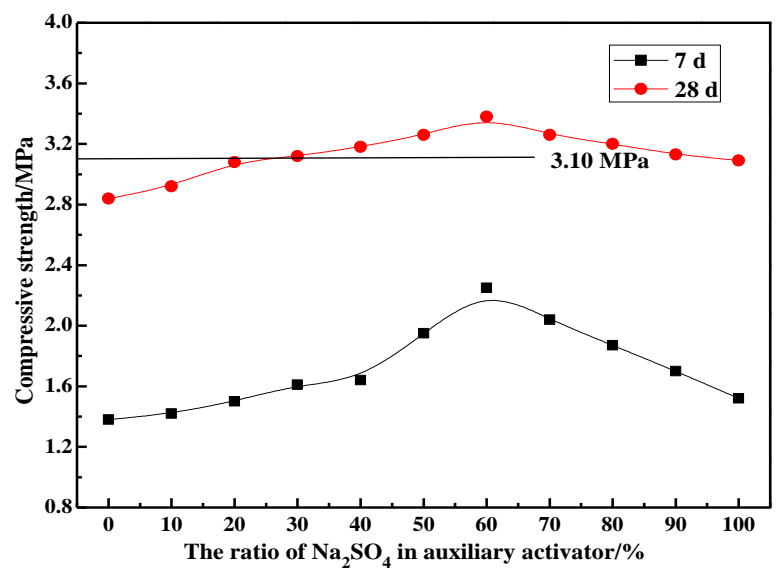

Figure 6. Effect of $\mathrm{Na}_{2} \mathrm{SO}_{4}$ content on compressive strength of CPB material 


\subsection{Phase composition and morphology of CA}

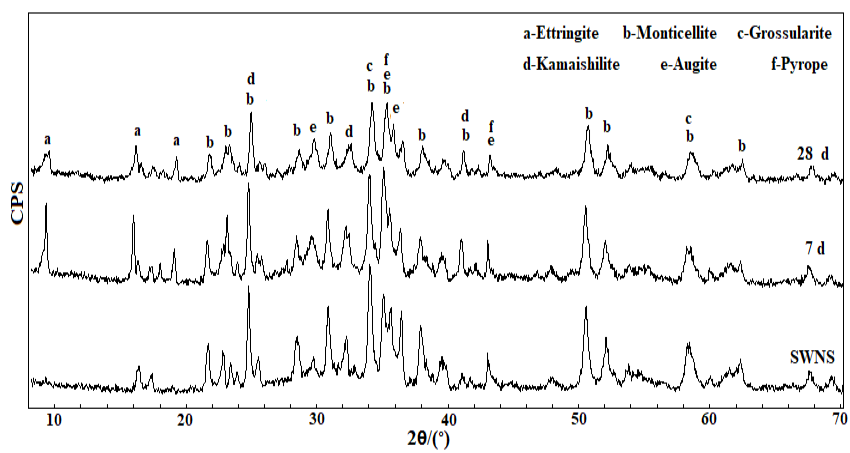

Figure7. XRD spectrum of paste block of CA and SWNS

Figure 7 shows the XRD patterns of SWNS, $\mathrm{Na}_{2} \mathrm{SO}_{4}, \mathrm{CC}$, FGDG and CS with corresponding mass fractions of $85 \%, 3 \%$, $2 \%, 5 \%$ and $5 \%$ of CA after hydration for $7 \mathrm{~d}$ and $28 \mathrm{~d}$. The main mineral phases are ettringite (AFt), monticellite, grossularite, kamaisshilite, augite and pyrope. From the comparison of the three diffraction curves in Fig. 7, it can be seen that, compared with the diffraction curves of SWNS, only $9.645 \AA, 5.576 \AA$ and $4.679 \AA$, which represent AFt, can be clearly identified as the new crystalline phase after $7 \mathrm{~d}$ and 28 $\mathrm{d}$ hydration of CA prepared with SWNS as the main raw materials, as the diffraction peaks of AFt and other crystalline phases in SWNS overlap superimposed, they cannot be clearly identified in the XRD pattern. The diffraction peak of AFt at 7 $\mathrm{d}$ after CA hydration is sharper than that of AFt at $28 \mathrm{~d}$. It is said that the crystallinity of the hydration products at $28 \mathrm{~d}$ is lower than that of the hydration products at $7 \mathrm{~d}$, that is, a large number of amorphous substances are produced at $28 \mathrm{~d}$.

Figure 8 shows the SEM photos of CA paste block on curing $7 \mathrm{~d}$ and $28 \mathrm{~d}$. According to Figure 8(a), it can be seen that the micro morphology of the paste block at the time of CA hydration $7 \mathrm{~d}$, after curing, the main hydration products of the paste block were a large amount of low-crystallinity or amorphous C-S-H gels and a small amount of fibrous hydration product $\mathrm{AFt}$, the accumulation of hydration products is not close enough, indicating that the sample of CA has undergone a certain degree of hydration reaction. Figure $8(\mathrm{~b})$ shows the enlargement of the labeled area in Figure 8(a), and a large number of AFt formation of acicular or fibrous hydration products can be seen.
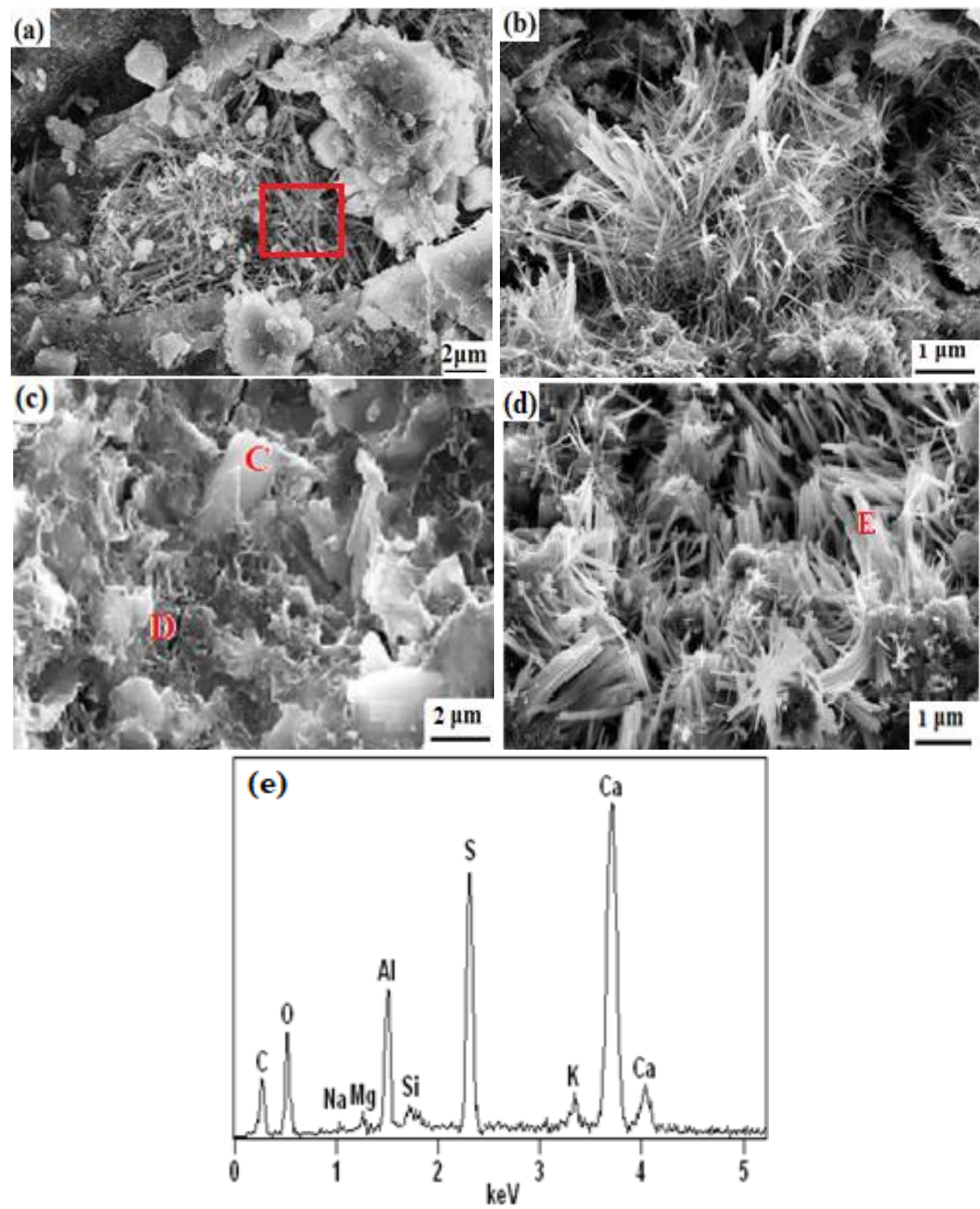

Figure 8. SEM images and EDS spectrum of CA samples at different ages. (a) and (b)-7 d, (c), (d) and (e)-28 d 
As can be seen from Figure 8(c), a large number of flocculent gels grew around the particles (see D point in Figure $8(\mathrm{c})$ ) in the paste block (see Figure 8(c)), this indicates that the crystalline material and glass phase in SWNS are fully stimulated to participate in the hydration reaction. It can be seen in the Figure 8(c) that the particles are embedded in the hydration products, and the boundary of the particles is blurred, the hydration products glue a large number of particles together and form a piece, the gap between the particles is greatly reduced, which increases the compactness of the slurry. Figure $8(d)$ is a local enlarged view of Figure 8(c). It can be seen from the figure that a large number of long-rod-shaped AFt are observed, and most of them grow in radial bundles. Compared with hydration products at $7 \mathrm{~d}$ of hydration, hydration products at $28 \mathrm{~d}$ of CA become thicker and shorter, and the long rod-shaped AFt and crystalline C-S-H gels grow better, making the structure become very dense, and no obvious large holes can be observed, which makes the paste block have good mechanical strength on the macro level. The energy spectrum semi-quantitative analysis of these long rodshaped products (Figure 8(e)) was conducted, which was speculated to be AFt, which was also consistent with the analysis results of XRD (Figure 7).

\subsection{Hydration mechanism of CPB material}

The strength source of CPB material of SWNS is a combination of alkali activator and sulfate activator to joint excitation. When the four activators of FGDG, CS, $\mathrm{Na}_{2} \mathrm{SO}_{4}$ and $\mathrm{CC}$ are matched according to the appropriate proportion, the CPB material of SWNS is of high strength.

In the early stage of $\mathrm{OH}^{-}$hydration, $\mathrm{C}_{3} \mathrm{~A}$ and $\mathrm{C}_{4} \mathrm{AF}$ in $\mathrm{CC}$ system react with $\mathrm{CaSO}_{4} \cdot 2 \mathrm{H}_{2} \mathrm{O}$ to form $\mathrm{AFt}$ and $\mathrm{Ca}(\mathrm{OH})_{2}$. Since the amount of $\mathrm{CC}$ is low, this reaction can only generate a small amount of $\mathrm{AFt}$, while the resulting $\mathrm{CC}$ hydration generates $\mathrm{Ca}(\mathrm{OH})_{2}$ as alkali activator that will continue to react with SWNS. Meanwhile, FGDG and $\mathrm{Na}_{2} \mathrm{SO}_{4}$ in $\mathrm{CA}$ reacted with SWNS as sulfate activator and $\mathrm{CS}$ as alkali activator. CS provides sufficient $\mathrm{Ca}(\mathrm{OH})_{2}$ in the early hydration reaction, so that the system contains higher concentration of $\mathrm{OH}^{-}$, this part of $\mathrm{OH}^{-}$and the $\mathrm{OH}^{-}$released from the $\mathrm{CC}$ are the main sources of "alkali" in the alkali excitation of CPB material of SWNS. As can be seen from Fig. 4, when the content of FGDG is $100 \%$ (that is, CS is not added), the compressive strength of the samples prepared on $7 \mathrm{~d}$ and $28 \mathrm{~d}$ is very low, indicating that CS is particularly important in stimulating the bonding strength of SWNS.

The incorporation of $\mathrm{Na}_{2} \mathrm{SO}_{4}$ will greatly affect the dissolution of CS. This is because $\mathrm{Na}_{2} \mathrm{SO}_{4}$ reacts with $\mathrm{Ca}^{2+}$ in the system to form $\mathrm{CaSO}_{4} \cdot 2 \mathrm{H}_{2} \mathrm{O}$ with very low solubility:

$$
\begin{gathered}
\mathrm{Ca}(\mathrm{OH})_{2}+2 \mathrm{Na}^{+}+\mathrm{SO}_{4}{ }^{2-} \\
+2 \mathrm{H}_{2} \mathrm{O}=\mathrm{CaSO}_{4} \cdot 2 \mathrm{H}_{2} \mathrm{O}+2 \mathrm{Na}^{+}+2 \mathrm{OH}^{-}
\end{gathered}
$$

This reaction indicated that the presence of $\mathrm{Na}_{2} \mathrm{SO}_{4}$ would accelerate the dissolution rate of $\mathrm{CS}$, resulting in a higher $\mathrm{pH}$ value of the solution than that of saturated $\mathrm{Ca}(\mathrm{OH})_{2}$ solution, thus continuously dissolving silicate and aluminosilicate vitreous under the erosion of high concentration $\mathrm{OH}^{-}$, accelerating the alkali excited reaction of the system. At the same time, because the $\mathrm{pH}$ value of the system is much higher than that of OPC slurry, it can also stimulate the volcanic activity of some crystalline materials in SWNS so that they also participate in the hydration reaction. In addition, the introduction of $\mathrm{Na}_{2} \mathrm{SO}_{4}$ increased the concentration of $\mathrm{SO}_{4}{ }^{2-}$, so that more AFt could be generated in the early stage. In summary, the early strength of sulphate-induced SWNS is attributed to two factors: the acceleration of the early volcanic ash reaction (active silicon and aluminum from the dissolution of SWNS) and the formation of AFt. As an activator, FGDG provides necessary substances for the formation of AFt.

The $\mathrm{Ca}^{2+}$ and $\mathrm{Mg}^{2+}$ on the vitreous surface of SWNS can adsorb $\mathrm{OH}^{-}$to form hydroxides, thus damaging the surface structure of SWNS and promoting the hydration of SWNS. The bond strength of $\mathrm{Ca}-\mathrm{O}$ and $\mathrm{Mg}-\mathrm{O}$ bonds in the external body of SWNS network are much stronger than those of Si-O and Al-O bonds, so the network structure of SWNS glass body dominated by $\left[\mathrm{AlO}_{4}\right]^{5-}$ tetrahedron and $\left[\mathrm{SiO}_{4}\right]^{4-}$ tetrahedron can be destroyed. Si-O-Al and Al-O-Al in the vitreous of SWNS were eroded by $\mathrm{OH}^{-}$, and $\mathrm{Al}^{3+}$ was gradually released. The concentration of $\mathrm{AlO}_{2}{ }^{-}$in the solution increases and reacts with $\mathrm{Ca}^{2+}$ and $\mathrm{SO}_{4}{ }^{2-}$ to form $\mathrm{AFt}\left(3 \mathrm{CaO} \cdot \mathrm{Al}_{2} \mathrm{O}_{3} \cdot 3 \mathrm{CaSO}_{4} \cdot 32 \mathrm{H}_{2} \mathrm{O}\right)$. A certain amount of alkali activator can destroy the vitreous network structure of SWNS and promote hydration. An appropriate amount of sulfate activator can provide $\mathrm{Ca}^{2+}, \mathrm{SO}_{4}^{2-}$ to produce the hydration product AFt.

\section{CONCLUSIONS}

(1) The SWNS after molten iron extraction from nickel slag contains both glass phase and crystalline material, and the excitation effect of FGDG and CS alone is weak. The special $\mathrm{CA}$ for $\mathrm{CPB}$ mining can be prepared by adding composite activator, which can meet the requirements of mine CPB.

(2) With FGDG and CS as the main activator, $\mathrm{Na}_{2} \mathrm{SO}_{4}$ and $\mathrm{CC}$ as the auxiliary activator, $\mathrm{CA}$ was prepared from SWNS, FGDG, $\mathrm{CS}, \mathrm{Na}_{2} \mathrm{SO}_{4}$ and $\mathrm{CC}$ by mass ratios of $85 \%, 5 \%, 5 \%$, $3 \%$ and $2 \%$, then the $\mathrm{CPB}$ materials with a slurry concentration of $80 \%$ is made by the ratio CA/IOT of $1: 4$. The $28 \mathrm{~d}$ flexural strength and compressive strength can reach $1.99 \mathrm{MPa}$ and $3.38 \mathrm{MPa}$, meet the requirements of CPB material $(28 \mathrm{~d}$ flexural strength $\geq 1.9 \mathrm{MPa}$, compressive strength $\geq 3.1 \mathrm{MPa}$ ).

(3) The results of XRD, SEM analysis and hydration mechanism show that the hydration products of the prepared $\mathrm{CA}$ are C-S-H gel and AFt. During the hydration of CA, the network structure of $[\mathrm{AlO} 4]^{5-}$ tetrahedron and $[\mathrm{SiO} 4]^{4-}$ tetrahedron in SWNS glass phase is destroyed. $\mathrm{Ca}^{2+}$ and $\mathrm{Mg}^{2+}$ participate in the reaction to form hydrated aluminosilicate (CM-S-H) gel containing $\mathrm{Ca}^{2+}$ and $\mathrm{Mg}^{2+}$, which plays an important role in the continuous increase of the strength of CPB material in the later stage.

\section{ACKNOWLEDGMENTS}

The authors gratefully acknowledge financial support from China Postdoctoral Science Foundation (Grant No.: 2016M602082), supported by Natural Science Foundation of Hebei Province (Grant No.: E2018402119), supported by Natural Science Foundation of Shaanxi Province (Grant No.: 2019JLM-49), supported by Shaanxi Science and Technology Benefit People Project (Grant No.: 2018ZY-HM-01), supported by Science and Technology Research Project of Higher Education Universities in Hebei Province (Grant No.: ZD2016014, QN2016115), supported by Comprehensive Utilization of Tailing Resources Key Laboratory of Shaanxi Province (Grant No.: 2017SKY-WK008), supported by 
Jiangxi Postdoctoral Daily Fund Project (Grant No.: 2016RC30), supported by Jiangxi Postdoctoral Research Project (Grant No.: 2017KY19), supported by State Key Laboratory of Solid Waste Reuse for Building Materials (Grant No.: SWR-2019-008, SWR-2017-006).

\section{REFERENCES}

[1] Deng, D.Q., Liu, L., Yao, Z.L., Song, K.I.I.L., Lao, D.Z. (2017). A practice of ultra-fine tailings disposal as filling material in a gold mine. Journal of Environmental Management, 196: 100-109. https://doi.org/10.1016/j.jenvman.2017.02.056

[2] Wu, A.X. (2011). Review on paste filling with tailings disposal technology. Mining Equipment, (4): 32-35.

[3] Ghirian, A, Mamadou, F. (2016). Strength evolution and deformation behaviour of cemented paste backfill at early ages: Effect of curing stress, filling strategy and drainage. International Journal of Mining Science and Technology, 26(5):

809-817. https://doi.org/10.1016/j.ijmst.2016.05.039

[4] Ghirian, A. (2016). Coupled thermo-hydro-mechanicalchemical (THMC) processes in cemented tailings backfill Structures and implications for their engineering design. Ottawa: University of Ottawa.

[5] Yilmaz, E., Belem, T., Benzaazoua, M. (2014). Effects of curing and stress conditions on hydromechanical, geotechnical and geochemical properties of cemented paste backfill. Engineering Geolegy, 168: 23-37. https://doi.org/10.1016/j.enggeo.2013.10.024

[6] Kesimal, A., Yilmaz, E., Ercikdi, B., Alp, I., Deveci, H. (2005). Effect of properties of tailings and binder on the short-and long-term strength and stability of cemented paste backfill. Materials Letters, 59(28): 3703-3709. https://doi.org/10.1016/j.matlet.2005.06.042

[7] Benzaazoua, M., Marion, P., Picquet, I., Bussière, B. (2004). The use of pastefill as a solidification and stabilization process for the control of acid mine drainage. Minerals $\quad$ Engineering, 17(2): 233-243. https://doi.org/10.1016/j.mineng.2003.10.027

[8] Su, L., Zhang, X.H. (2013). Coordinated development between mineral resource exploitation and environmental protection with backfill technology. Mining and Metallurgical Engineering, 33(3): 117-121.

[9] Benzaazoua, M., Bussière, B., Demers, I., Aubertin, M., Fried, É., Blier, A. (2008). Integrated mine tailings management by combining environmental desulphurization and cemented paste backfill: Application to mine Doyon, Quebec, Canada. Minerials Engineering, 21(4): 330-340. https://doi.org/10.1016/j.mineng.2007.11.012

[10] Peyronnard, O., Benzaazoua, M. (2012). Alternative byproduct based binders for cemented mine backfill: Recipes optimisation using Taguchi method. Minerials Engineering, 29: 28-38 https://doi.org/10.1016/j.mineng.2011.12.010

[11] Yilmaz, E., Belem, T., Bussière, B., Mbonimpa, M., Benzaazoua, B. (2015). Curing time effect on consolidation behaviour of cemented paste backfill containing different cement types and contents. Construction and Building Materials, 75: 99-111. https://doi.org/10.1016/j.conbuildmat.2014.11.008

[12] Li, W.C., Fall, M. (2016). Sulphate effect on the early age strength and self-desiccation of cemented paste backfill. Construction and Building Materials, 106: 297304. https://doi.org/10.1016/j.cemconcomp.2017.09.019

[13] Yılmaz, T., Ercikdi, B., Karaman, K., Külekçi, G. (2014). Assessment of strength properties of cemented paste backfill by ultrasonic pulse velocity test. Ultrasonics, 54(5):

1386-1394. https://doi.org/10.1016/j.ultras.2014.02.012

[14] Ke, X., Hou, H.B., Zhou, M., Wang, Y., Zhou, X. (2015). Effect of particle gradation on properties of fresh and hardened cemented paste backfill. Construction and Building Materials, 96: 378-382. https://doi.org/10.1016/j.conbuildmat.2015.08.057

[15] Ercikdi, B., Cihangir, F., Kesimal, A., Deveci, H., Alp, L. (2009). Utilization of industrial waste products as pozzolanic material in cemented paste backfill of high sulphide mill tailings. Journal of Hazardous Materials, 168(2): 848-856. https://doi.org/10.1016/j.jhazmat.2009.02.100

[16] Reddy Bellum, R., Muniraj, K., Madduru, S.R.C. (2019). Empirical relationships on mechanical properties of class-f fly ash and GGBS based geopolymer concrete. Annales de Chimie - Science des Matériaux, 43(3): 189197. https://doi.org/10.18280/acsm.430308

[17] Deng, X.J., Zhang, J.X., Klein, B., Zhou, N., deWit, B. (2017). Experimental characterization of the influence of solid components on the rheological and mechanical properties of cemented paste backfill. International Journal of Mineral Processing, 168: 116-125. https://doi.org/10.1016/j.minpro.2017.09.019

[18] Li, X.B., Du, J., Gao, L., He, S.Y., Gan, L., Sun, C., Shi, Y. (2017). Immobilization of phosphogypsum for cemented paste backfill and its environmental effect. Journal of Cleaner Production, 156: 137-146. https://doi.org/10.1016/j.jclepro.2017.04.046

[19] Lu, Y.Q., Li, M. (2019). Solidification of heavy metals in waste incineration fly ashes with silica-alumina composite. Annales de Chimie - Science des Matériaux, 43(5): 293-298. https://doi.org/10.18280/acsm.430503

[20] Li, Y.C., Min, X.B, Ke, Y., Chai, L.Y., Shi, M.Q., Tang, C.J., Wang, Q.W., Liang, Y.J., Lei, J., Liu, D.G. (2018). Utilization of red mud and $\mathrm{Pb} / \mathrm{Zn}$ smelter waste for the synthesis of a red mud-based cementitious material. Journal of Hazardous Materials, 34: 343-349. https://doi.org/10.1016/j.jhazmat.2017.10.046

[21] Ren, C., Li, K.Q., Ni, W., Zhang, S.Q. (2019). Preparation of mine filling material from steel slag mud. Annales de Chimie - Science des Matériaux, 43(4): $217-$ 224. https://doi.org/10.18280/acsm.430404

[22] Li, W.C., Fall, M. (2018). Strength and self-desiccation of slag-cemented paste backfill at early ages: Link to initial sulphate. Cement and Concrete Composites, 89: 160-168. https://doi.org/10.1016/j.cemconcomp.2017.09.019

[23] Chen, Q.S., Zhang, Q.L., Fourie, A., Chen, X., Qi, C.C. (2017). Experimental investigation on the strength characteristics of cement paste backfill in a similar stope model and its mechanism. Construction and Building Materials, 154: 34-43. https://doi.org/10.1016/j.conbuildmat.2017.07.142

[24] Yilmaz, E., Belem, T., Benzaazoua, M. (2015). Specimen size effect on strength behavior of cemented paste backfills subjected to different placement 
conditions. Engineering Geology, 185: 52-62. https://doi.org/10.1016/j.enggeo.2014.11.015

[25] Jia, Q., Yang, Q.X., Guo, L.J., Knutsson, S., Xue, P., Liu, G.Q., Jiang, L. (2016). Effects of fine content, binder type and porosity on mechanical properties of cemented paste backfill with co-deposition of tailings sand and smelter slag. Electronic Journal of Geotechnical Engineering, 21: 7017-7032.

[26] Cihangir, F., Akyol, Y. (2018). Mechanical, hydrological and microstructural assessment of the durability of cemented paste backfill containing alkali-activated slag. International Journal of Mining, Reclamation and Environment, $32(2)$ : $123-143$ https://doi.org/10.1080/17480930.2016.1242183

[27] Lee, H.J., Roh, H.S. (2007). The use of recycled tire chips to minimize dynamic earth pressure during compaction of backfill. Construction and Building Materials, 21: 1016-1026. https://doi.org/10.1016/j.conbuildmat.2006.02.003

[28] Benzaazoua, M., Fiset, J.F., Bussière, B., Villeneuve, M., Plante, B. (2006). Sludge recycling within cemented paste backfill Study of the mechanical and leach ability properties. Minerals Engineering, 19: 420-432. https://doi.org/10.1016/j.mineng.2005.09.055

[29] Ercikdi, B., Cihangir, F., Kesimal, A., Deveci, H., Aip, İ. (2009). Utilization of industrial waste products as pozzolanic material in cemented paste backfill of high sulphide mill tailings. Journal of Hazardous Materials,
168: https://doi.org/10.1016/j.jhazmat.2009.02.100

$848-856$

[30] Ashrit, S., Chatti, R.V., Udpa, K.N., Venugopal, R., Nair, U.G. (2017). An Infrared and Raman spectroscopic study of yellow Gypsum synthesized from LD slag fines. MOJ Mining and Metallurgy, 1(1): 1-4.

[31] Zhang, Q.L., Ji, T., Yang, Z.X., Wang, C.Q., Wu, H.C. (2020). Influence of different activators on microstructure and strength of alkali-activated nickel slag cementitious materials. Construction and Building Materials, 235: 117449-117456. https://doi.org/10.1016/j.conbuildmat.2019.117449

[32] Yang, T., Wu, Q.S., Zhu, H.J., Zhang, Z.H. (2017). Geopolymer with improved thermal stability by incorporating high-magnesium nickel slag. Construction and Building Materials, 155: 475-484. https://doi.org/10.1016/j.conbuildmat.2017.08.081

[33] Huang, Y.D., Wang, Q., Shi, M.X. (2017). Characteristics and reactivity of ferronickel slag powder. Construction and Building Materials, 156: 773-789. https://doi.org/10.1016/j.conbuildmat.2017.09.038

[34] Wu, Q.S., Wu, Y., Tong, W.H., Ma, H.E. (2018). Utilization of nickel slag as raw material in the production of Portland cement for road construction. Construction and Building Materials, 193: 426-434. https://doi.org/10.1016/j.conbuildmat.2018.10.109 